\title{
The effect of upstream buildings on near-field pollutant dispersion in the built environment
}

\author{
B. Hajra ${ }^{a^{*}}$, T. Stathopoulos ${ }^{\mathrm{a}}$, A. Bahloul ${ }^{\mathrm{b}}$ \\ ${ }^{\text {a }}$ Centre for Building Studies, Department of Building, Civil and Environmental \\ Engineering, Concordia University, Montreal, Canada \\ ${ }^{b}$ Institut de recherche Robert-Sauvé en santé et en sécurité du travail, Montreal, Canada
}

\begin{abstract}
This paper examines the effects of near-field pollutant dispersion characteristics of upstream buildings in the built environment and compares them to the ASHRAE 2007 model. Wind tunnel simulations were performed for nine different building configurations for three exhaust momentum ratios $(M)$ and three stack heights $\left(h_{s}\right)$. The effect of spacing (S) between the buildings and stack location from the upwind edge of the emitting building $(\mathrm{X})$ were also investigated. Measurements of gas concentrations were performed on the roof and leeward wall of the emitting and upstream buildings. Data show that within the recirculation zone a change in along wind dimension of the upstream building has a negligible effect on the dilution of emissions from the downwind building. However, spacing between buildings and the height of the upstream building were found to be critical parameters in assessing plume dilutions. The plume geometry is largely governed by the upwind dimensions of the upstream building. ASHRAE 2007 predicts lower dilutions for all cases examined, leading to conservative or very conservative design. Additionally, ASHRAE 2007 cannot model the effect of upstream buildings requiring further investigation of its formulations. Guidelines for placement of intake and stack on the roof of the building to avoid problems of re-ingestion are discussed.
\end{abstract}

Keywords: Dispersion; Wind tunnel; Upstream building; Recirculation zone; Stack; ASHRAE 2007

\footnotetext{
*Corresponding author.Tel.001-514-848-2424; ext: 3211

E-mail address: b_hajra@encs.concordia.ca
} 


\section{Introduction}

Pollutant concentrations in the near-field are a cause for concern for most health physicists and regulatory agencies. Pollutants released from rooftop stacks within the recirculation zone may not only re-enter the building from which they are released but may also affect an adjacent building in the near-vicinity (Stathopoulos et al., 2008).

Most studies pertaining to near-field pollutant dispersion have mostly focussed on isolated buildings (Wilson, 1979; Schulman and Scire, 1991 etc.) with very few studies on adjacent building effects which deems to be more realistic. The flow-structure of the plume is greatly influenced by a building in the near vicinity, as opposed to far-field problems where atmospheric turbulence is more important. There is no accurate way to distinguish between near-field and far-field dispersion problems. Wilson et al., 1998, based on water channel measurements to assess plume behaviour in the presence of adjacent buildings, defined near-field to be within the "recirculation region" from the source, which is estimated from ASHRAE 2007 based on the upwind building dimensions.

In addition to ASHRAE, numerous dispersion models have been used to assess plume dilutions in the presence of buildings such as PRIME and ADMS. ADMS-BUILD was first described in the EUROMECH conference held in Lisbon in 1982 (Hunt and Robins, 1982) and its current version, ADMS 4, is a modified version of ADMS-BUILD. An extensive study on the suitability of these models to simulate dispersion of pollutants for the case of isolated buildings was carried out by the authors (see Stathopoulos et al., 2008). The study showed that most of these models were incapable of assessing plume dilutions within the recirculation length of the building where the flow structure is complex. Higher rooftop concentrations were predicted and the results were overly conservative (Hajra et al., 2010). Most validation studies for ADMS were carried out using field and wind tunnel data for far-field dispersion problems such as field studies from American Gas Association experiments (Engineering Science, 1980) where plumes were released from elevated stacks and receptors were located on the ground more than $50 \mathrm{~m}$ away. Regarding ADMS and other Environmental Protection Agency (EPA) models Riddle et al., 2004 declared "such atmospheric dispersion packages are not able to assess the local effects of a complex of buildings on the flow field and turbulence, and 
whether gas will be drawn down amongst the buildings." In 1992 the Electric Power Research Institute (EPRI) in USA decided to improve the Industrial Source Complex model (ISC) by incorporating downwash effects. The evaluation of AERMOD, ADMS and PRIME was carried out by Hanna et al., 2010 by comparing them with five different sets of field measurements. The study reported that dilutions predicted by PRIME were lower than field data. A common feature of most EPA models is that they are not suitable to estimate concentrations on walls or roofs of buildings and are mostly used for groundlevel receptors. ASHRAE is the only Gaussian-based model available to estimate concentrations on the rooftop of buildings.

This paper presents wind tunnel results for nine different configurations, three different stack heights $\left(h_{s}\right)$ of 1,3 and $5 \mathrm{~m}$ and exhaust momentum ratios (M) ranging from 1 to 3 at horizontal wind azimuth of $0^{\circ}$, i.e. perpendicular to the building face, within the recirculation region of the source. $M$ is equivalent to the ratio of exhaust speed $\left(V_{e}\right)$ to the wind velocity at building height $\left(\mathrm{U}_{\mathrm{H}}\right)$. The experiments were performed in the open circuit Boundary Layer Wind Tunnel of Concordia University. The buildings used in this study have a flat roof, with receptors located on the building roof, windward and leeward wall.

Section 2 of this paper describes the airflow and pollutant transport within the recirculation zone of a building, followed by formulations of ASHRAE 2007 in section 3. The wind tunnel experimental set up and the various configurations examined have been discussed in sections 4 and 5 respectively. Section 6 presents the results and discussion followed by design guidelines in section 7 . Summary and conclusions are presented in section 8 .

\section{Airflow and pollutant transport within building recirculation region}

When wind strikes a building it undergoes flow separations at the edges and formation of recirculation zone (shown as $L_{c}$ and $L_{r}$ respectively in Figure 1. According to ASHRAE 2007 the size of the recirculation region at the wake (shown as $L_{r}$ in Figure 1) is estimated by using the building dimensions perpendicular to wind direction:

$L_{r}=B_{s}{ }^{0.67} B_{L}{ }^{0.33}$ 
where:

$L_{r}$ is the length of the zone of recirculating flow (m),

$B_{S}$ is the smaller building dimension perpendicular to wind direction (m),

$B_{L}$ is the larger building dimension perpendicular to wind direction (m).

The calculation of $L_{r}$ is based on the work of Wilson, 1979. Different approaches for the evaluation of recirculation length are also available (ADMS and PRIME) and results will be presented and discussed further in this paper. As shown in Figure 1, the building generally affects the flow up to about 1.5 times ' $\mathrm{R}$ ' from the roof of the building, where ' $\mathrm{R}$ ' is the scaling length for roof flow patterns, noted as $L_{r}$. in Equation 1. The recirculation zone formed on the roof tries to engulf a portion of the plume thereby bringing it closer to the roof surface, though this phenomenon is gradually reduced with higher exhaust speeds. Note that the plume trajectory shown in Figure 2, which is based on water channel studies by Wilson et al., 1998, is no more than a notional single realisation and that over time a very wide range of 'trajectories' would be observed, not all of which would travel upstream.

However, most previous studies did not focus on a detailed analysis by considering change in various parameters such as the upstream building dimensions, change in stack height and location, varying exhaust speeds etc, which are focussed in the present study.

\section{ASHRAE 2007}

ASHRAE 2007 has devised two techniques: The Geometric design method and the Gaussian plume equations. The former is used for assessing minimum stack height to avoid plume material entering the recirculation region, whereas the latter is used to estimate plume dilutions at a given rooftop receptor.

\subsection{Geometric design method}

The geometric design method is based on the geometry of the plume as shown in

Figure 1. The dimensions of flow re-circulation zones that form on the building and Roof-Top Structure (RTS) are:

$H_{c}=0.22 R$

$X_{c}=0.5 R$ 
where: $H_{c}$ is the maximum height of the roof recirculation zone $(\mathrm{m})$,

$\mathrm{X}_{\mathrm{c}}$ is the distance from the leading edge to $\mathrm{H}_{\mathrm{c}}(\mathrm{m})$,

$\mathrm{L}_{\mathrm{c}}$ is the length of the roof recirculation zone $(\mathrm{m})$

However, this method cannot be used to find the dilution at a given receptor, which is important for assessing the suitability of the location of the intake structure.

\subsection{Gaussian plume equations}

To assess plume dilutions on a rooftop receptor, ASHRAE 2007 suggests the use of Gaussian equations. Some of the parameters required for assessing dilutions include the effective height of the plume (h) above the roof:

$h=h_{s}+h_{r}-h_{d}$

where:

$\mathrm{h}_{\mathrm{s}}$ is stack height $(\mathrm{m})$,

$\mathrm{h}_{\mathrm{r}}$ is plume rise $(\mathrm{m})$ and

$h_{d}$ is the reduction in plume height due to entrainment into the stack wake during periods of strong winds $(\mathrm{m})$.

Plume rise, calculated using the formula of Briggs, 1984, which is assumed to occur instantaneously, is only due to momentum:

$h_{r}=3 \beta d_{e}\left(V_{e} / U_{H}\right)$

where: $d_{e}$ is the stack diameter $(m)$,

$\mathrm{V}_{\mathrm{e}}$ is the exhaust velocity $(\mathrm{m} / \mathrm{s})$,

$\mathrm{U}_{\mathrm{H}}$ is the wind speed at building height $(\mathrm{m} / \mathrm{s})$

and $\beta$ is the stack capping whose value is 1 for uncapped stacks and 0 for capped stacks. The effect of plume buoyancy is not taken into account.

Wilson et al., 1998 recommended a stack wake downwash adjustment $h_{d}$, which is defined as:

$h_{d}=d_{e}\left(3-\beta V_{e} / U_{H}\right)$

The dilution $\mathrm{D}_{\mathrm{r}}$ is defined as:

$\mathrm{D}_{\mathrm{r}}=\mathrm{C}_{\mathrm{e}} / \mathrm{C}_{\mathrm{r}}$ 
$\mathrm{C}_{\mathrm{e}}=$ contaminant mass concentration in exhaust, $\mathrm{kg} / \mathrm{m}^{3}$

$\mathrm{C}_{\mathrm{r}}=$ contaminant mass concentration in receptor, $\mathrm{kg} / \mathrm{m}^{3}$

Dilution at roof level in a Gaussian plume emitted at the final rise plume height of $\mathrm{h}$ is:

$$
D_{r}=4\left(U_{H} / V_{e}\right)\left(\sigma_{y} / d_{e}\right)\left(\sigma_{z} / d_{e}\right) \exp \left(\zeta^{2} / 2 \sigma_{z}{ }^{2}\right)
$$

where: $\zeta=\mathrm{h}-\mathrm{H}_{\mathrm{c}}$

$$
=0 \text { if } \mathrm{h}<\mathrm{H}_{\mathrm{c}}
$$

$\zeta$ is the vertical separation between ' $\mathrm{h}$ ' and $\mathrm{H}_{\mathrm{c}}$.

Equation 8 is simply the inverse of a standard Gaussian plume expression for ground level concentrations, with the emission rate $(\mathrm{Q})$ expressed in terms of the source diameter and emission speed. For the present study the dilutions calculated from Equation 8 have been converted to normalised dilutions for ease of comparison with previous studies:

$$
\mathrm{D}_{\text {normalised }}=\left(\mathrm{D}_{\mathrm{r}} \mathrm{Q}\right) /\left(\mathrm{U}_{\mathrm{H}} \mathrm{H}^{2}\right)
$$

\section{Wind tunnel experimental setup and simulation conditions}

Wind tunnel experiments were performed at the open circuit boundary layer wind tunnel at Concordia University. The wind tunnel is $1.8 \mathrm{~m}$ square in section and $12.2 \mathrm{~m}$ in length. Spires, which act as vorticity generators and coarse roughness elements, were used to generate a thick atmospheric boundary layer with a power law exponent $(\alpha)$ of 0.31, which corresponds to an urban terrain exposure according to ASHRAE 2009. The wind tunnel floor panels had $5 \mathrm{~cm}$ cubes that were arranged staggered and spaced about 6 $\mathrm{cm}$ from each other. The velocity and turbulence intensity profiles are shown in Figure 3. The flow in the wind tunnel was turbulent with stable time-averaged flow conditions throughout the tests. The roof of the tunnel was adjusted to ensure that the longitudinal static pressure gradient was negligible. The front view section of the wind tunnel is shown in Figure 4. The model value of the longitudinal integral scale was $0.4 \mathrm{~m}$, which corresponds to a full-scale value of $80 \mathrm{~m}$. The model roughness length of the upstream exposure was $3.5 \mathrm{~mm}$, which corresponds to a full-scale roughness length of $0.7 \mathrm{~m}$. The gradient height (boundary layer thickness) was $95 \mathrm{~cm}$. The wind speed at building height $\left(\mathrm{U}_{\mathrm{H}}\right)$ was measured to be $6.2 \mathrm{~m} / \mathrm{s}$ in the wind tunnel. Good comparisons were found 
between turbulence intensity measured in the wind tunnel and that obtained from Engineering Science Data Unit (ESDU, 1974) for similar conditions.

Tracer gas consisting of a mixture of sulphur hexafluoride $\left(\mathrm{SF}_{6}\right)$ and nitrogen was released at $\mathrm{M}$ ranging from 1 to 3 and $\mathrm{h}_{\mathrm{s}}$ from $1 \mathrm{~m}$ through $5 \mathrm{~m}$ from a stack whose diameter was $3 \mathrm{~mm}$ representing a full scale value of $0.6 \mathrm{~m}$. The measurements were generally made once the wind tunnel was stable after about 4 minutes of operation. The height of the wind tunnel is sufficient for the horizontal and vertical development of the plume. The samples of $\mathrm{SF}_{6}$ were collected from each receptor using tubes connected to a syringe sampler, which could suck the samples during a period of one minute. Background concentrations are not likely to affect the measurements due to the efficient ventilation facility and the volume of the laboratory. Detailed previous experiments involving wind tunnel measurements of $\mathrm{SF}_{6}$ on surface of model cubes at Concordia University found that subtracting background porosity made negligible difference on the results (Saathoff et al., 1995). A Gas Chromatograph (GC) was used to assess the concentration of the syringe samplers. Deviations in concentrations were within $\pm 15 \%$, which is generally considered to be acceptable (Stathopoulos et al., 2008).

Snyder, 1981, suggested that the following criteria need to be satisfied for modelling non-buoyant plume exhaust:

- Geometric similarity

- Building Reynolds Number $>11000$

- Stack Reynolds Number $>2000$

- Similarity of wind tunnel flow with atmospheric surface layer

- Equivalent stack momentum ratio.

For pollutant dispersion studies performed in the wind tunnel it is very important to maintain turbulent flow around the building and stack. In the present study, the building and stack Reynolds number were measured to be 20000 and 1800 respectively. Saathoff et al., 1995 suggested that "it is generally not possible to satisfy the stack Reynolds number for small diameter stacks and it is also difficult to trip the flow for such stacks". Although, the stack Reynolds number is somewhat less than 2000, this may have had minimal effect on the measurement results, as discussed in Hajra et al., 2010. 
When the stack and receptor are in close proximity to each other, as in the present study, the effects of averaging time are not expected to affect the measurements. ASHRAE 2007 suggests that an averaging time of 2 minutes correspond to full-scale averaging time of one hour. However, equivalent averaging time is dependent on model scale and wind speed, i.e. scale time is $\mathrm{L}_{\text {ref }} / \mathrm{U}_{\text {ref. }}$. Averaging is also dependent on the spatial turbulence scales present. Since, neither very large geophysical scales nor large diurnal scales are present in the wind tunnel, after some model time all averages will be equivalent. In general, it has been found by experimental comparison of plume spreading, that a well-modeled wind tunnel plume spreads at a rate equivalent to about $1 / 2$ hour averages in the field.

In the present study the averaging time for collecting samples was one minute because the instrument used for collecting the samples is only capable of measuring samples at a maximum averaging time of one minute.

\section{Configurations examined}

Six building models made of wood were used for the study. Nine different configurations were examined to assess near-field plume characteristics in the presence of upstream buildings. The dimensions of each building model are presented in Table 1.

Table 1 Dimensions of building models used for wind tunnel experiments

\begin{tabular}{|l|l|l|l|l|l|}
\hline Building & Height $(\mathrm{m})$ & Width $(\mathrm{m})$ & Breadth $(\mathrm{m})$ & \multicolumn{2}{|c|}{ Recirculation Length } \\
\cline { 4 - 6 } & & & & ASHRAE (Eq.1) & ADMS/PRIME (Eq.10) \\
\hline $\mathrm{B}_{1}$ & 15 & 50 & 50 & 22.3 & 35.9 \\
\hline $\mathrm{B}_{2}$ & 30 & 50 & 30 & 35.5 & 50.0 \\
\hline $\mathrm{B}_{3}$ & 30 & 50 & 15 & 35.5 & 79.1 \\
\hline $\mathrm{B}_{4}$ & 30 & 30 & 30 & 30.0 & 43.5 \\
\hline $\mathrm{B}_{5}$ & 54 & 50 & 15 & 51.2 & 55.6 \\
\hline $\mathrm{B}_{6}$ & 30 & 50 & 50 & 35.5 & \\
\hline
\end{tabular}

The predictions of ADMS/PRIME are based on Fackrell and Pearce, 1981:

$$
L_{r}=\frac{1.8 W}{\left[(L / H)^{0.3}(1+0.24 W / H)\right]}
$$

$$
(0.3 \leq L / H \leq 3.0)
$$


When the ratio of $L / H$ lies outside the indicated range, $L_{r}$ is computed using the nearer limit. Table 1 shows that based on ASHRAE calculations, the lowest value of recirculation length is $22.3 \mathrm{~m}$ and the highest is $51.2 \mathrm{~m}$. However, ADMS/PRIME predicts higher values than ASHRAE 2007, which uses the values of $L_{r}$ to assess rooftop dilutions. In Equation 8, $\zeta$ is defined as the difference between $\mathrm{h}$ and $\mathrm{H}_{\mathrm{c} .}$, which is the maximum height of the roof recirculation zone and is calculated from Equation 2 as a function of $\mathrm{R}\left(\mathrm{L}_{\mathrm{r}}=\mathrm{R}\right)$,. If ASHRAE 2007 predictions of $\mathrm{L}_{r}$ were higher (such as those in ADMS), values of $\zeta$, would eventually lead to lower dilutions (higher rooftop concentrations) making the results even more conservative.

Figures 5 and 6 present the different configurations along with stack and receptor locations on the building. The receptors are located only along the building centerline and not laterally over the various surfaces; they are $5 \mathrm{~m}$ apart on the roof, windward and leeward walls of the low and intermediate emitting buildings. For configurations involving taller upstream building, receptors were located $10 \mathrm{~m}$ apart on the windward wall and $5 \mathrm{~m}$ apart on the leeward wall of the upstream building with very few receptors located on the roof of the upstream building. For configurations involving the intermediate emitting building receptors were located about $10 \mathrm{~m}$ apart on the windward and leeward walls of the upstream building with very few receptors on the roof.

Although, tests were carried out for wind azimuth $(\theta)$ of $0^{\circ}, 22.5^{\circ}$ and $45^{\circ}, \theta=0^{\circ}$ was found to be the most critical; hence results in this paper are only restricted to $\theta=0^{\circ}$. The stack location from the upwind edge of the emitting building (X) was varied from $0 \mathrm{~m}$ to $20 \mathrm{~m}$.

\section{Results and discussion}

Figure 7 shows comparisons between data from present study and wind tunnel data from Schulman and Scire, 1991 in terms of normalised dilutions for the single building case to test the reliability of the present study results. Despite the differences in the experimental conditions (see details in Table 2) results are similar. There is good agreement between the results from the present study with those reported by Schulman and Scire, 1991, especially at points farther away from the stack. It is worth noting that 
although building heights and stack heights are similar, the building is larger and the exposure is suburban, as opposed to urban in the present study.

Table 2 Experimental parameters used for the present and previous studies.

\begin{tabular}{|l|l|l|}
\hline Experimental parameters & Present study & $\begin{array}{l}\text { Schulman and } \\
\text { Scire, 1991 }\end{array}$ \\
\hline Model scale & $1: 200$ & $1: 100$ \\
\hline Wind speed at building height $(\mathrm{m} / \mathrm{s})$ & 6.2 & 1.37 \\
\hline Upstream terrain & Urban & Suburban \\
\hline Power law exponent & 0.31 & 0.20 \\
\hline Stack diameter $(\mathrm{m})$ & 0.6 & 0.75 \\
\hline Building height $(\mathrm{m})$ & 15 & 15 \\
\hline Building width $(\mathrm{m})$ & 50 & 75 \\
\hline Building breadth $(\mathrm{m})$ & 50 & 75 \\
\hline
\end{tabular}

NB: Width refers to building dimension perpendicular to wind direction at $0^{\circ}$.

Results in this paper are shown for the roof and leeward wall of the emitting building and leeward wall of the taller upstream building for all upstream configurations because tracer gas was only found at these locations.

\subsection{Effect of a taller upstream building}

The effects of placing a taller building upstream are presented in Figures 8 through 10. It may be noted that Configurations 2 through 5 correspond to a taller upstream building.

\subsubsection{Dilutions on rooftop of emitting building $\left(B_{1}\right)$ for $X=0$}

Figure 8 shows comparisons of dilutions between Configurations 1 through 5 and ASHRAE 2007 at rooftop receptors on the $15 \mathrm{~m}$ high building $\left(\mathrm{B}_{1}\right)$ for a stack placed at the upwind edge of $\mathrm{B}_{1}(\mathrm{X}=0)$ for $\mathrm{S}=20 \mathrm{~m}$. Figure 8 (a) shows comparable dilutions obtained at all receptors for Configurations 1 through 4 indicating that a change in along wind and across wind dimension of the upstream building did not affect the rooftop dilutions at $\mathrm{M}=1$. It was also observed that Configuration 5 produced measurable dilutions at only the first two points from the edge. This is probably due to the recirculation length of the upstream building $\left(\mathrm{B}_{5}\right)$, which is quite large $(51.2 \mathrm{~m})$ and possibly forces at least a major part of the plume to affect the leeward wall of the 
upstream building with a portion of it getting trapped between the buildings. Furthermore, the plume may not follow a path in line with the stack but may actually travel along the sides of the emitting building due to the turbulence created in the wake of the upstream building. However, at $\mathrm{h}_{\mathrm{s}}=1 \mathrm{~m}$ and $\mathrm{M}=3$, although comparable dilutions were found for Configurations 2 and 3, Configuration 4 produced somewhat higher dilutions than Configuration 2. This is because the across wind dimension of the upstream building in Configuration 4 is smaller than that of the emitting building, resulting in a reduced recirculation length $(30 \mathrm{~m})$; this effect is more predominant at $\mathrm{M}=$ 3 because downwash effects are reduced and the plume has a greater scope to escape the recirculation cavity of the upstream building. The dilutions for Configurations 2, 3 and 4 were generally lower than the isolated case. When $h_{s}>1 \mathrm{~m}$ the plume height increases further and hence the effects of the upstream building greatly reduce, as shown in Figure 8 (c) where dilutions for Configurations 2, 3 and 4 are comparable to the isolated case. A similar trend is observed for greater $h_{s}=3 \mathrm{~m}$ and $\mathrm{M}=3$, as shown in Figure $8(\mathrm{~d})$. ASHRAE 2007 predicts lower dilutions for all configurations, clearly because it does not consider the effect of turbulence generated by the upstream building or stack and local topography.

\subsubsection{Dilutions on leeward wall of the upstream building ( $B_{2}, B_{3}$ and $\left.B_{4}\right)$}

Normalised dilutions on leeward walls of $\mathrm{B}_{2}$ (Configuration 2), $\mathrm{B}_{3}$ (Configuration 3 ) and $\mathrm{B}_{4}$ (Configuration 4) are displayed in Figure 9 (a) for $\mathrm{h}_{\mathrm{s}}=1 \mathrm{~m}$ and $\mathrm{M}=1$. ASHRAE 2007 does not predict dilutions on the leeward walls of a building and can only be used to estimate dilutions on the rooftop of the building. The upstream building in these configurations is twice the height of the emitting building. Comparable dilutions for Configurations 2 and 3 were found at all points on the leeward wall of the buildings while Configuration 4 resulted in almost 10 times higher dilutions than Configurations 2 and 3. This is because Configuration 4 has a reduced across wind dimension of the upstream building resulting in a smaller recirculation length created by the upstream building. A similar trend is also observed for $M=3$ as shown in Figure 9 (b). Similar observations were noted for stack located at $\mathrm{X}=20 \mathrm{~m}$. At $\mathrm{h}_{\mathrm{s}}>1 \mathrm{~m}$ no dilution was reported on the leeward wall of the upstream building because the plume height is more than $3 \mathrm{~m}$ above 
the building surface for stack heights greater than $1 \mathrm{~m}$ (say for $\mathrm{h}_{\mathrm{s}}=3 \mathrm{~m}$ ) at low $\mathrm{M}$ values. This makes the plume spread quickly along the surface of the emitting building thereby leaving the upstream building unaffected. When the stack was placed at $20 \mathrm{~m}$ away from the upwind edge of the building the tracer concentrations were so greatly diluted that they were undetectable on the leeward wall of the upstream building.

Comparable dilutions between all configurations were also reported on the leeward wall of $B_{1}$ for $h_{s}=1 \mathrm{~m}$ and $M=1$. At $h_{s}$ greater than $1 \mathrm{~m}$ concentration of the gas was greatly reduced because of greater stack height, which resulted in a smaller portion of pollutants being engulfed within the recirculation length downwind of $\mathrm{B}_{1}$.

\subsubsection{Dilutions on rooftop of the emitting building $\left(B_{1}\right)$ at $X=20 \mathrm{~m}$}

Figure 10 (a) shows rooftop dilution comparisons for Configurations 1 through 5 and ASHRAE 2007 for $\mathrm{h}_{\mathrm{s}}=1 \mathrm{~m}, \mathrm{M}=1$ at $\mathrm{X}=20 \mathrm{~m}$. It may be noted that Configurations 3 and 5 have $B_{3}$ and $B_{5}$ upstream of $B_{1}$ respectively, also the height of $B_{5}$ is nearly twice as much as that of $\mathrm{B}_{3}$ (see Figures 5). Therefore, dilutions on the roof of $\mathrm{B}_{1}$ in Configuration 5 are expected to be lower than those for Configuration 3 owing to the building's greater height in the former which tends to bring the plume towards the leeward wall of $\mathrm{B}_{5}$ and the upwind roof of $\mathrm{B}_{1}$, as explained previously. However, the dilutions become comparable beyond $20 \mathrm{~m}$ since the effect of upstream building height gradually reduces. Comparable dilutions for Configurations 2 and 3 are obtained at all points suggesting that for upstream buildings of equal height, a change in along wind dimension of the upstream building does not affect the rooftop concentrations of the emitting building. If the upstream building is longer the flow reattachment is likely to occur but since the heights of the two buildings are equal, turbulence generated in the wake of the upstream building is small thereby leaving the emitting building very little affected. Configuration 4 does not predict any concentrations on the rooftop of the emitting building within the first 20 $\mathrm{m}$. This is because the upstream building $\left(\mathrm{B}_{4}\right)$ has a smaller recirculation length $(30 \mathrm{~m})$ and since the stack is placed sufficiently away from the upwind edge, the plume geometry tends to be similar to an isolated building. ASHRAE 2007 predicts lower

dilutions than all configurations and does not report dilutions at receptors upwind of 
stack. A similar trend is also observed at $h_{s}=1 \mathrm{~m}$ and $\mathrm{M}=3$. At $\mathrm{h}_{\mathrm{s}}>1 \mathrm{~m}$ the dilutions obtained from all configurations become comparable at receptors downwind of stack.

\subsection{Effect of an upstream building of equal height}

Figure 11 (a) presents rooftop dilution comparisons for Configurations 6 through 9 and ASHRAE 2007 for $h_{s}=1 \mathrm{~m}, \mathrm{M}=1$ and $\mathrm{X}=0$. Data show comparable dilutions for all configurations within the first $20 \mathrm{~m}$ from the stack, following which, the dilutions obtained from the upstream configurations are lower than the isolated case. This is because the recirculation cavity in the wake of the upstream building is not sufficiently large to bring the plume towards itself but generates sufficient turbulence to keep the plume closer to the roof of $\mathrm{B}_{6}$. It may also be noted that Configuration 9 predicts higher dilutions than Configurations 7 and 8 beyond $30 \mathrm{~m}$ from the stack. This suggests that at low exhaust speeds and stack height a reduced across wind dimension of the upstream building increases rooftop dilutions on the emitting building which is similar to the findings of a taller upstream building discussed previously. It was observed that Configuration 7 produced somewhat lower dilutions than Configuration 8 at certain locations beyond $20 \mathrm{~m}$ from the stack, which suggests that at lower $\mathrm{M}$ and $\mathrm{h}_{\mathrm{s}}$ an increase in along wind dimension of the upstream building generates lower rooftop dilutions at some points on the emitting building compared to an upstream building with reduced along wind dimension. This is possibly because for an upstream building with greater along wind dimension, there is a likelihood of flow re-attachment which makes the recirculation zone rather weak on the leeward side of the upstream building; as a result, the plume is not drawn towards the upstream building and mostly affects the rooftop of the emitting building. This phenomenon is reduced at $h_{s}=1 \mathrm{~m}$ and $M=3$ as shown in Figure 11 (b) where comparable dilutions are obtained for Configurations 7, 8 and 9 at points beyond $25 \mathrm{~m}$ from the stack. At greater $\mathrm{h}_{\mathrm{s}}$ and $\mathrm{M}$ the dilutions obtained for all upstream configurations are comparable. Good comparisons were also obtained between model predictions and experimental data for the isolated case. When the stack is moved away from the edge comparable dilutions for all configurations and the isolated case were found. 


\subsection{Effect of spacing between buildings}

Figure 12 (a) shows normalised dilutions on the leeward wall of the upstream building for Configuration 3 for $\mathrm{h}_{\mathrm{s}}=1 \mathrm{~m}, \mathrm{M}=1$ and $\mathrm{X}=0$. Comparable dilutions were obtained for $\mathrm{S}=20 \mathrm{~m}$ and $\mathrm{S}=30 \mathrm{~m}$ at all receptors on the wall since both these distances are within the recirculation length of the upstream building $\mathrm{B}_{3}(35.5 \mathrm{~m})$. At $\mathrm{S}=40 \mathrm{~m}$ the dilutions are more than 10 times higher than those found at $\mathrm{S}=20 \mathrm{~m}$ since at distances beyond the recirculation length of $\mathrm{B}_{3}$ the plume does not affect the upstream building greatly; in fact, at $\mathrm{S}>40 \mathrm{~m}$ dilutions were so high that they were undetectable. Similar findings were reported for $h_{s}=1 \mathrm{~m}, \mathrm{M}=3$, as shown in Figure 12 (b) where although dilutions at $\mathrm{S}=20 \mathrm{~m}$ and $\mathrm{S}=30 \mathrm{~m}$ were comparable, no concentrations were found at $\mathrm{S}$ $=40 \mathrm{~m}$ because at higher $\mathrm{M}$ the effluents can and do escape the recirculation region of the upstream building.

Comparable dilutions were found at $\mathrm{S}=20 \mathrm{~m}, 30 \mathrm{~m}$ and $40 \mathrm{~m}$ on rooftop of $\mathrm{B}_{1}$ (emitting building) for Configuration 3 at $h_{s}=1 \mathrm{~m}, \mathrm{M}=1$ and $\mathrm{X}=0$, as shown in Figure 13 (a). This is because despite a change in spacing the plume always affects the emitting building. Similar observations were made at $h_{s}=1 \mathrm{~m}$ and $\mathrm{M}=3$ as shown in Figure 13 (b). Although the dilutions at $\mathrm{S}=20 \mathrm{~m}$ and $30 \mathrm{~m}$ are somewhat lower than those found at $\mathrm{S}=40 \mathrm{~m}$ and the isolated case (Configuration 1) trends are almost identical. ASHRAE 2007 predicts results only for the isolated case

\section{Design guidelines}

Based on the study it is clear that the suitable location of stacks and intakes on a building depends on a number of factors besides local topography and turbulence. Useful design guidelines have been formulated on the basis of research results but the safety of any possibly suggested location will really depend on the nature of the material released from stack. Suggested guidelines with this caveat may be summarised as follows:

\section{Taller upstream building}

1. When the spacing between the buildings exceeds the recirculation length of the upstream building (greater than about $30 \mathrm{~m}$ ) the dilutions generally increase on both the 
leeward wall of the upstream building and rooftop of the emitting building for any stack height and $\mathrm{M}$ value. Thus intakes can be considered on these building surfaces.

2. Similar to the isolated building case, when the emitting building is within the recirculation zone of the upstream building, for a stack placed at the upwind edge, intakes should not be located close to the stack. For such cases, high stacks and high $\mathrm{M}$ values should be used to avoid plume downwash effects. Intakes may be placed closer to the leeward wall of the emitting building.

3. When a lower stack (say less than $5 \mathrm{~m}$ ) is placed closer to the centre of the roof, within the recirculation zone of the upstream building, intakes should not be located upwind of the stack but they may be located on the leeward wall of the emitting building or on the roof of the upstream building. Similarly, when the spacing between the buildings exceeds the recirculation length of the upstream building, intakes may be better placed on the roof of the upstream building.

Upstream building of lower or equal height with the emitting building

1. For an upstream building of lower or equal height spaced sufficiently greater than the recirculation length of the upstream building, irrespective of stack location and height, intakes can be considered for placement on the roof of the upstream building.

2. When the buildings are spaced within the recirculation zone of the upstream building and regardless of stack location, intakes may be better placed on the leeward wall of the emitting building. Also, for centrally located stacks, intakes may be placed on roof upwind of them.

\section{Summary and conclusions}

Results of the study can be summarised for each case, as follows:

\section{Taller upstream building:}

1. Placement of the emitting building fully or partly within the re-circulated flow area of the upstream building is the most significant factor to determine the dilutions of exhaust on various building surfaces. For instance, when the upstream building is twice 
as high as the emitting building, a change in along wind dimension of the upstream building has a negligible effect on the rooftop and leeward wall of the emitting building.

2. For centrally placed stacks, reducing the across wind dimension of the upstream building (narrow building) generates a smaller recirculation length downwind producing concentrations only on receptors downwind of the stack. Further, the dilutions measured on the leeward wall of the upstream building increase significantly for higher stacks and higher $\mathrm{M}$ values.

Upstream building of lower or equal height with the emitting building

Irrespective of stack location, comparable rooftop dilutions on the emitting building were found for all configurations tested in the wind tunnel within the recirculation zone of the upstream building, although the dilutions are somewhat smaller than the isolated case at some locations. For lower stack height and exhaust momentum ratio, dilutions are similar at upstream roof locations.

\section{Effect of spacing (S) between the buildings}

1. For taller upstream buildings with stack placed at the upwind edge, dilutions on the leeward wall of the upstream building increase when the distance between the two buildings is greater than recirculation length of the upstream building, particularly for low $\mathrm{M}$ values.

2. Rooftop dilutions gradually increase (towards the isolated building case) as the spacing between the buildings exceeds recirculation length of the upstream building. Rooftop dilutions reduce significantly as the spacing between buildings approaches $20 \mathrm{~m}$ irrespective of the stack height and $\mathrm{M}$ value.

\section{ASHRAE 2007}

ASHRAE 2007 provisions are for isolated buildings and yield lower dilutions than the experimental measurements show for all configurations examined. Overall, they appear to be overly conservative since ASHRAE does not consider the effect of turbulence generated by upstream buildings and local topography. Additionally, ASHRAE refers only to roof surfaces and it cannot estimate dilutions on the leeward wall 
of the emitting or upstream building. Therefore, it is suggested that the plume rise calculations should take account of upstream buildings and the dilution estimates must also consider spacing between buildings, local topography and building dimensions.

\section{Acknowledgements}

The authors are thankful to the Institut de recherche Robert-Sauvé en santé et en sécurité du travail (IRSST), Montreal, Canada for funding this research.

\section{References}

ASHRAE, 2007. Building air intake and exhaust design. ASHRAE Applications Handbook, Chapter 44, American Society of Heating, Refrigerating and AirConditioning Engineering Inc., Atlanta, USA.

ASHRAE, 2009. Airflow around buildings. ASHRAE Applications Handbook, Chapter 24, American Society of Heating, Refrigerating and Air-Conditioning Engineers Inc., Atlanta, USA.

Briggs, G. A. 1984. Plume rise and buoyancy effects in atmospheric sciences and power production. D. Randerson, ed. US Department of Energy DOE/TIC-27601 (DE 84005177), Washington, DC, USA.

Engineering Science. 1980. Field validation of atmospheric dispersion models for natural gas compression stations. Report-PR-133, prepared for American Gas Association.

ESDU, 1974. Characteristics of atmospheric turbulence near the ground. Engineering Science Data Unit, no. 74030 and 74031, London, UK.

Fackrell J.E and Pearce J.E. 1981. Parameters affecting dispersion in the near wake of buildings, CEGB report RD/M/1179/N81.

Hajra, B., Stathopoulos, T., Bahloul, A. 2010. Assessment of pollutant dispersion from rooftop stacks: ASHRAE, ADMS and Wind Tunnel Simulation. Building and Environment, 45, 2768-2777.

Hanna, S.R., Egan, B.A., Purdum, J., Wagler, J. 2010. Evaluation of the ADMS, AERMOD, and ISC3 dispersion models with the optex, duke forest, kincaid, indianapolis, and lovett field data sets. International Journal of Environmental Pollution, vol.16, no-1-6. 
Hunt, JCR, Robins, AG, 1982. A model for assessing dispersion of plumes from sources in the vicinity of cuboid shaped buildings. Proceedings EUROMECH 162 (Ed: AR Janeiro Borges), 110-116, New University of Lisbon.

Riddle, A., Carruthers, D., Sharpe, A., Mc Hugh, C., Stocker, J. 2004. Comparisons between FLUENT and ADMS for atmospheric dispersion modeling. Atmospheric Environment, vol 38 (7), pp- 1029-1038.

Saathoff, P.J., Stathopoulos, T., Dobrescu, M. 1995. Effects of model scale in estimating pollutant dispersion near buildings. Journal of Wind Engineering and Industrial Aerodynamics. vol 54/55, pp-549-559.

Schulman, L.L., Scire, J.S. 1991. Effect of stack height, exhaust speed, and wind direction on concentrations from a rooftop stack. ASHRAE Transactions, 77, 573-585

Snyder, W. H. 1981. Guidelines for fluid modelling of atmospheric diffusion. EPA office of Air quality, planning and standards, Research Triangle Park, USA, EPA-600/8-81009.

Stathopoulos, T., Hajra, B., Bahloul, A. 2008. Analytical evaluation of dispersion of exhaust from rooftop stacks on buildings. IRSST research report R-576, Institut de recherche Robert-Sauvé en santé et en sécurité du travail, Montreal, Canada.

Wilson, D.J. 1979. Flow patterns over flat roofed buildings and application to exhaust stack design. ASHRAE Transactions, 85, 284-295.

Wilson, D. J. Fabris I, Ackerman M Y. 1998. Measuring adjacent effects on laboratory exhaust stack design. ASHRAE Transactions, 88 (1), 513-533. 


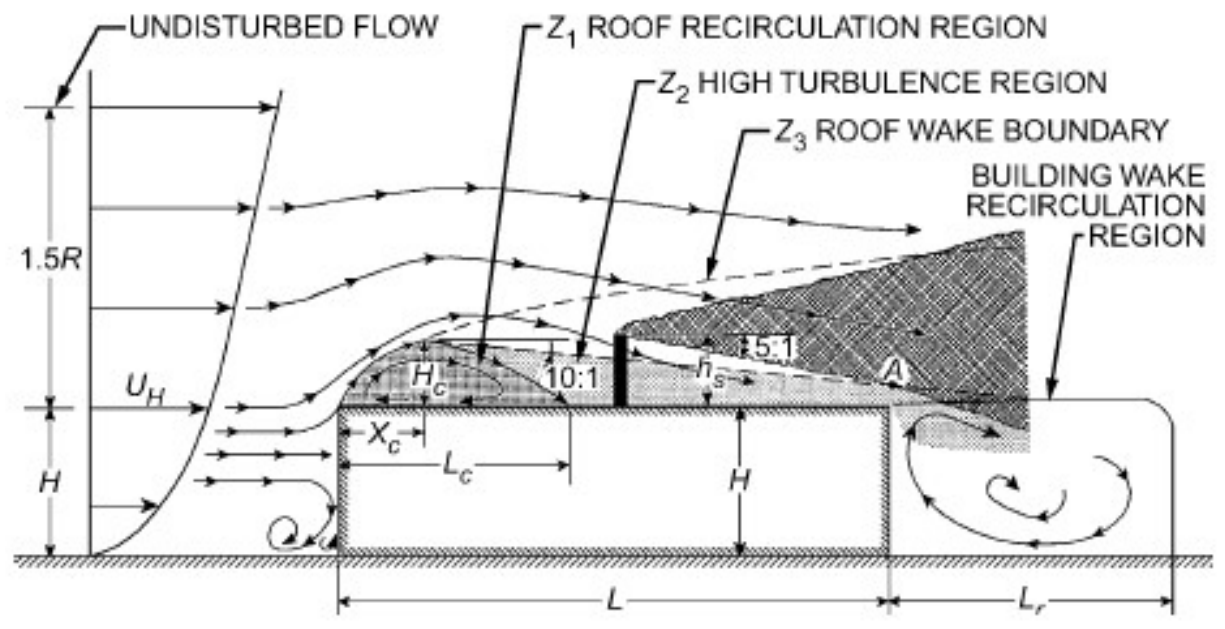

Figure 1. Design procedure for required stack height to avoid contamination (from Wilson, 1979)

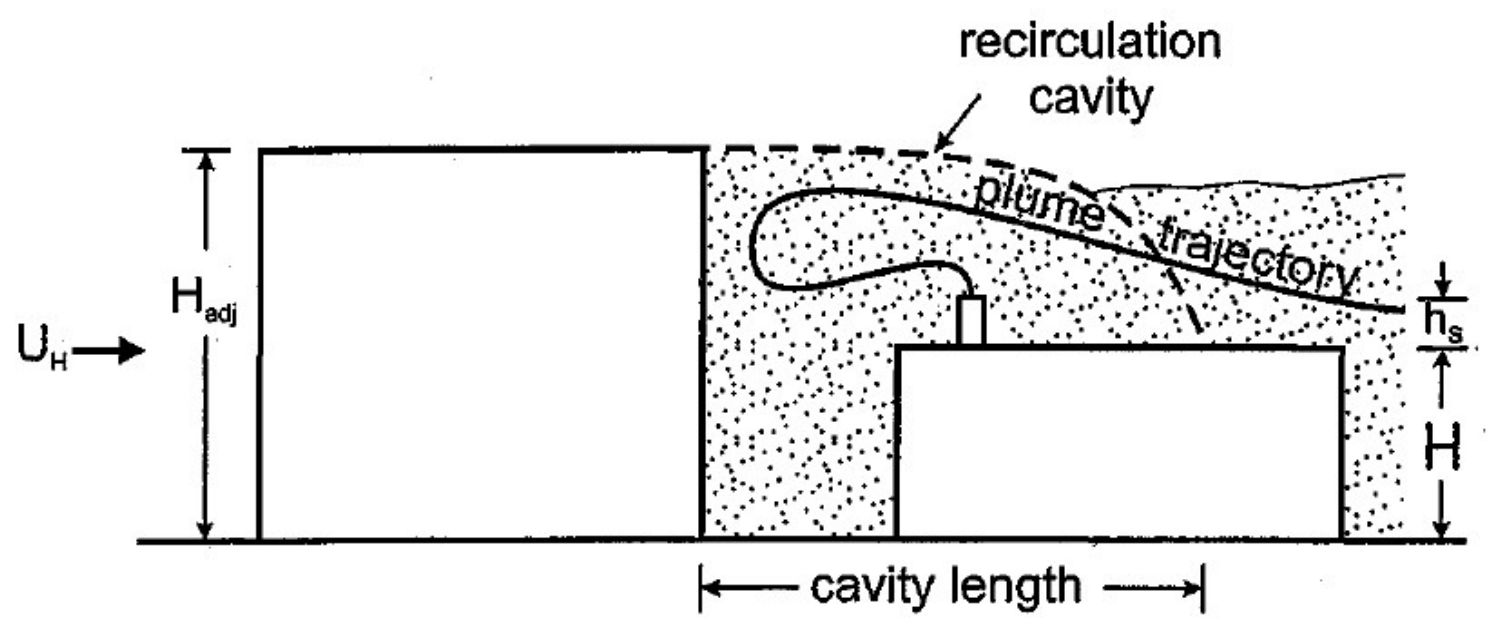

Figure 2 Recirculation cavity for a taller upstream building (from Wilson et al., 1998) 

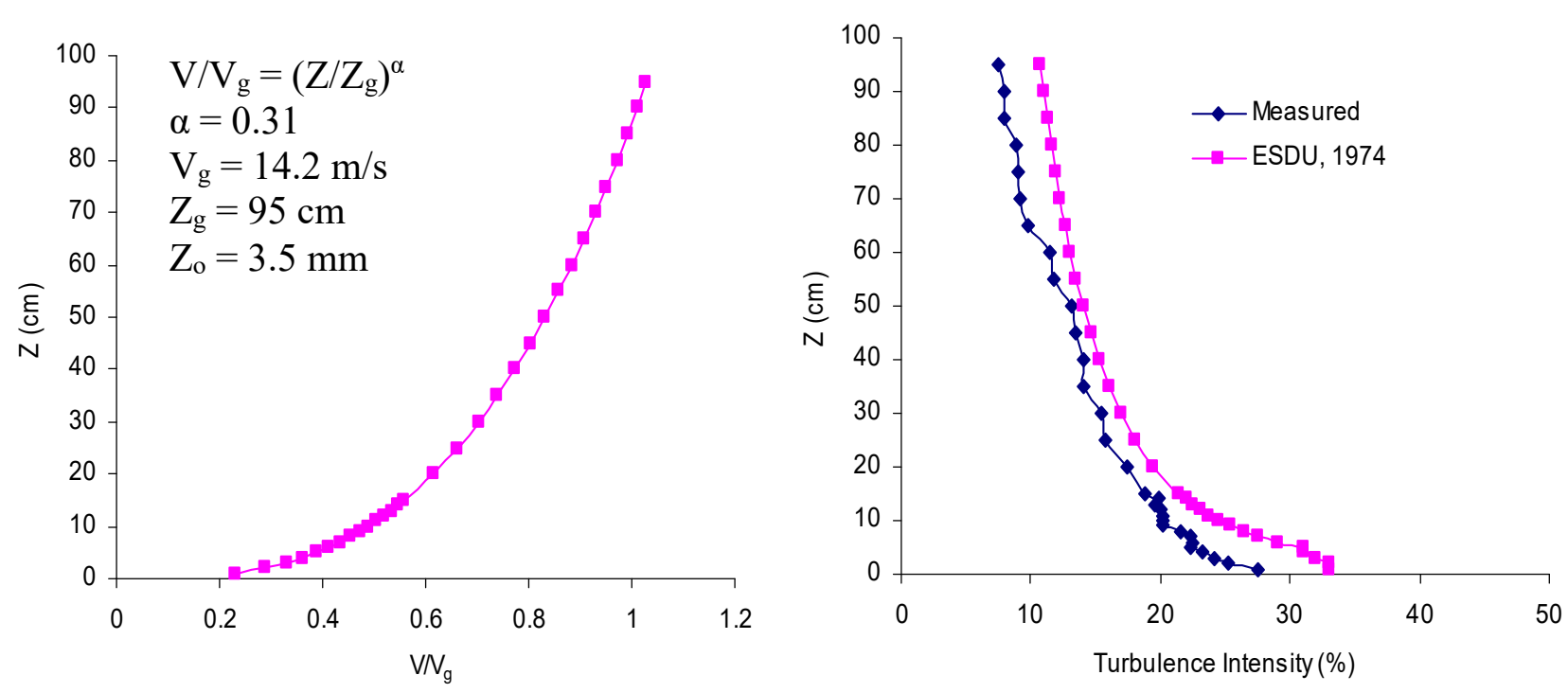

Figure 3 Mean velocity and turbulence intensity profiles measured at the Boundary Layer Wind tunnel of Concordia University.

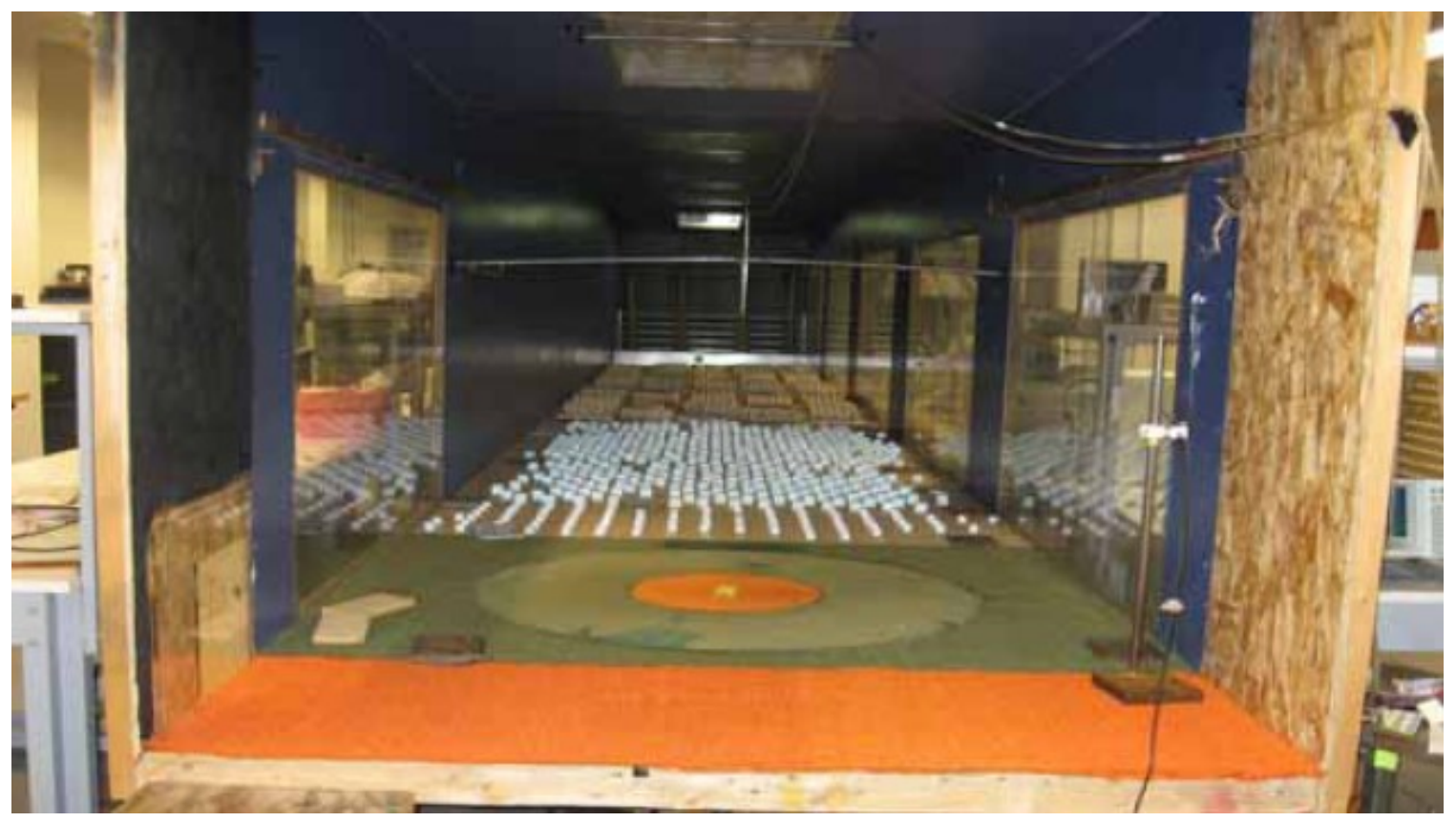

Figure 4 Front view section of the Boundary Layer Wind tunnel at Concordia University (from Stathopoulos et al., 2008). 


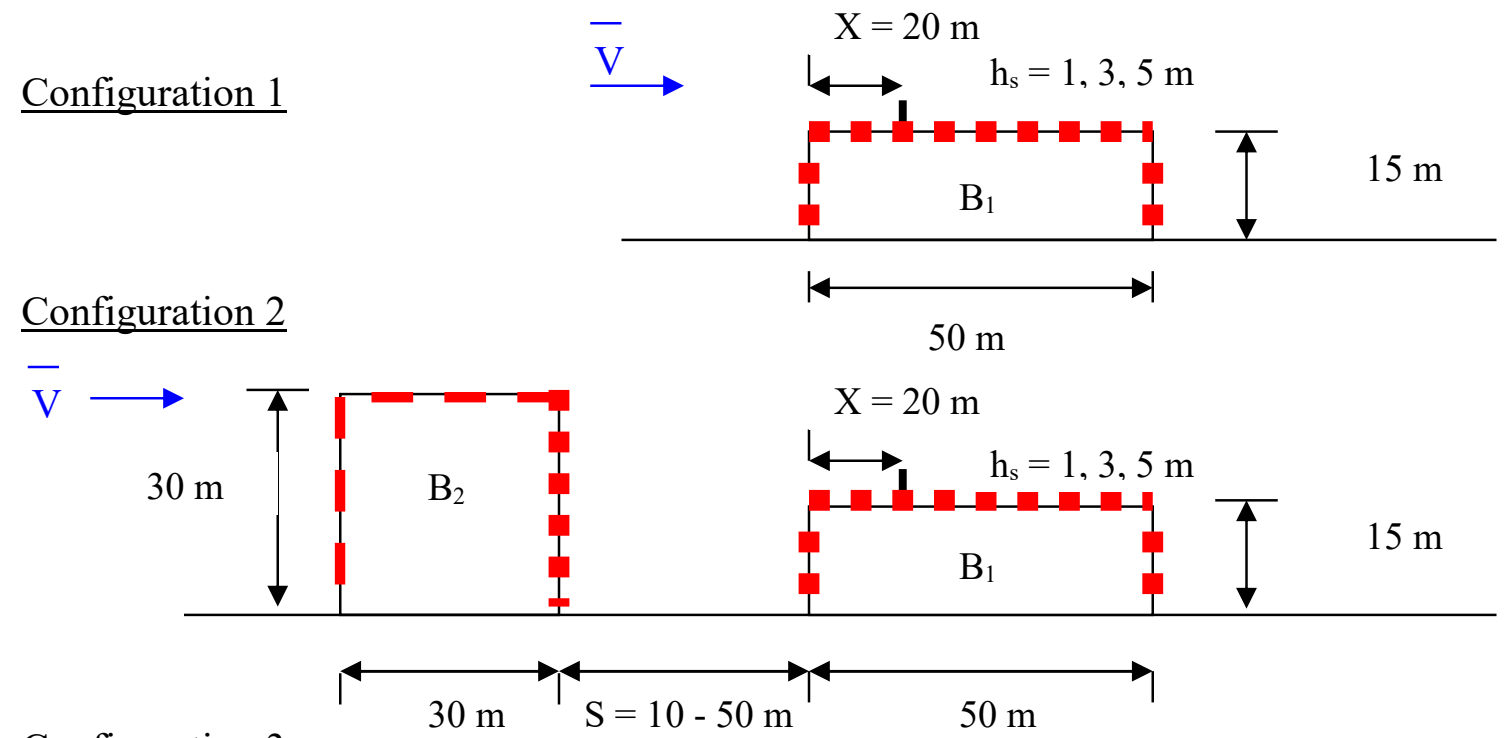

Configuration 3
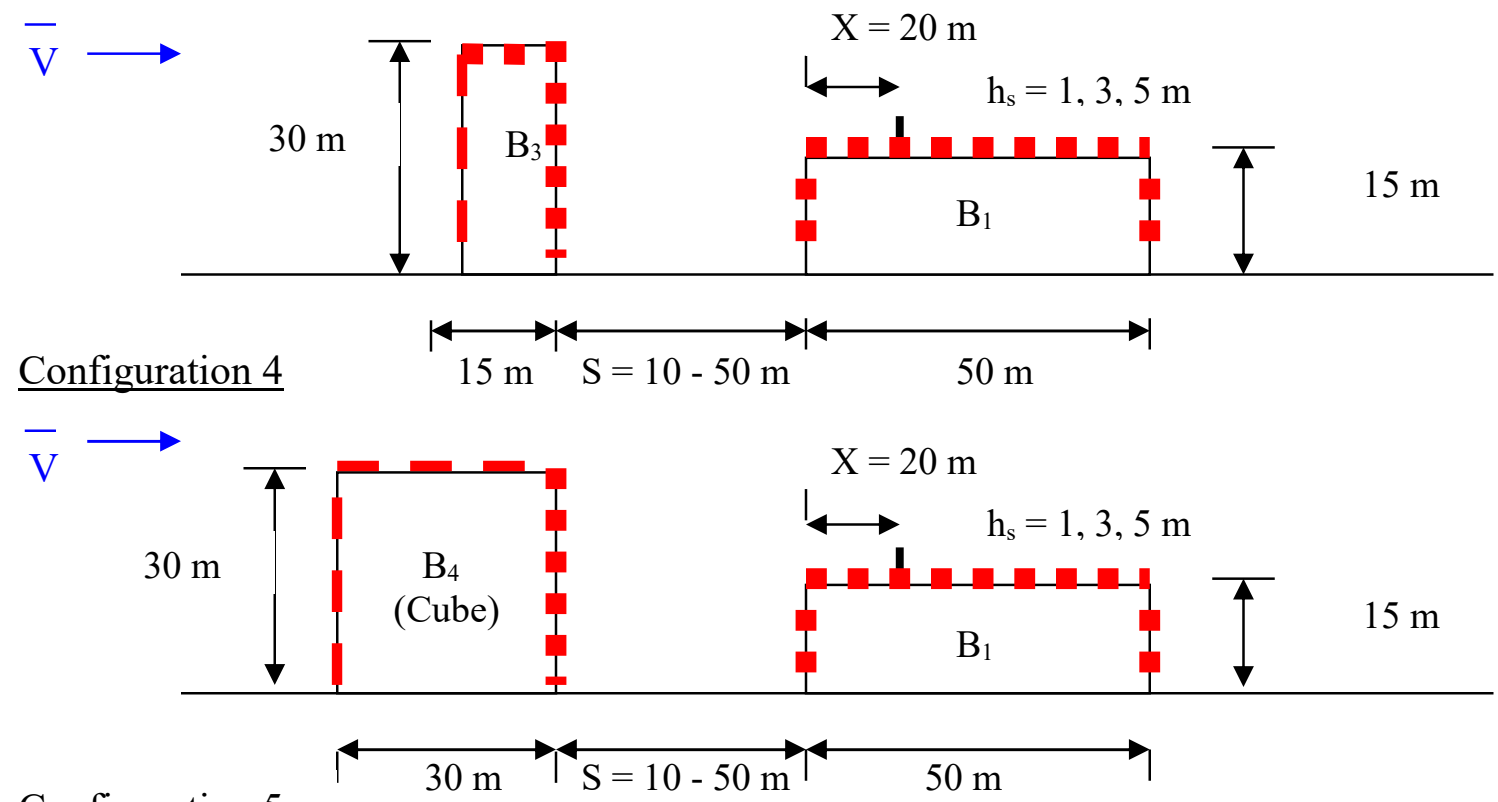

\section{$\underline{\text { Configuration } 5}$}
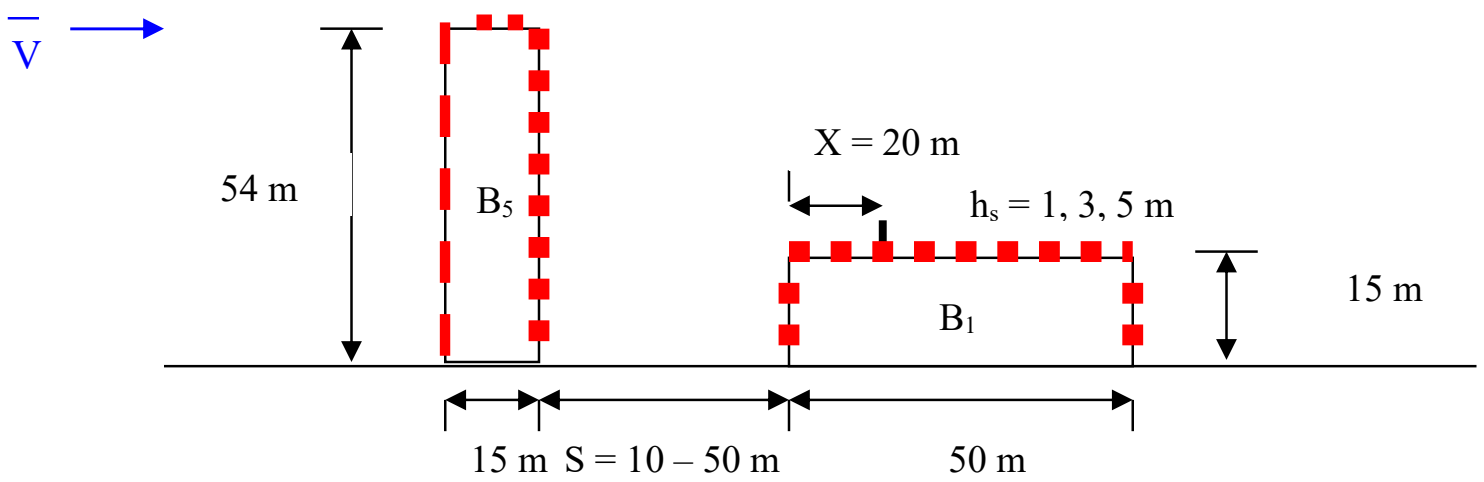

Figure 5: Configurations 1 to 5: Buildings of various geometries upstream of a low emitting building 

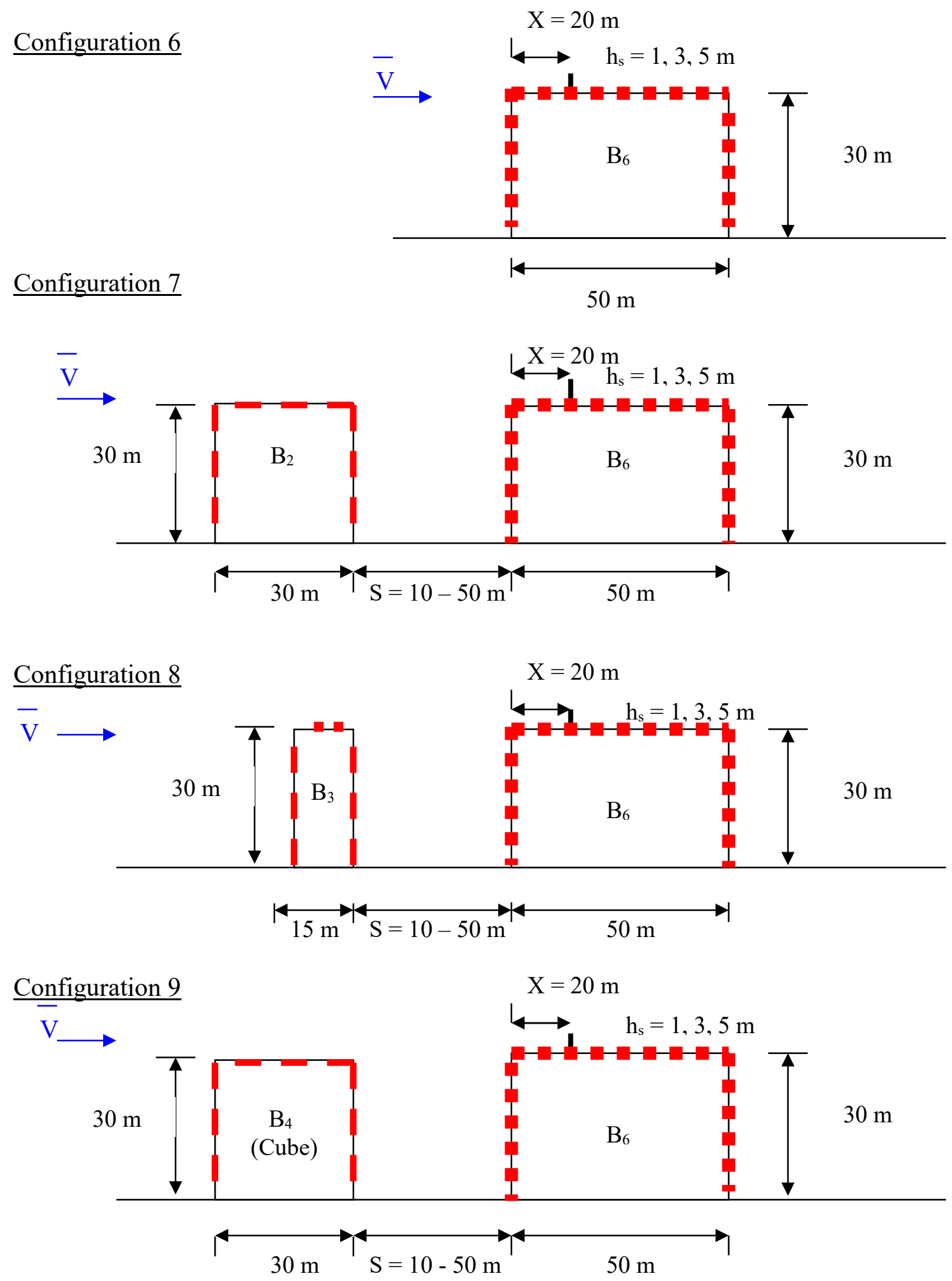

Figure 6: Configurations 6 to 9: Buildings of various geometries upstream of an intermediate emitting building 


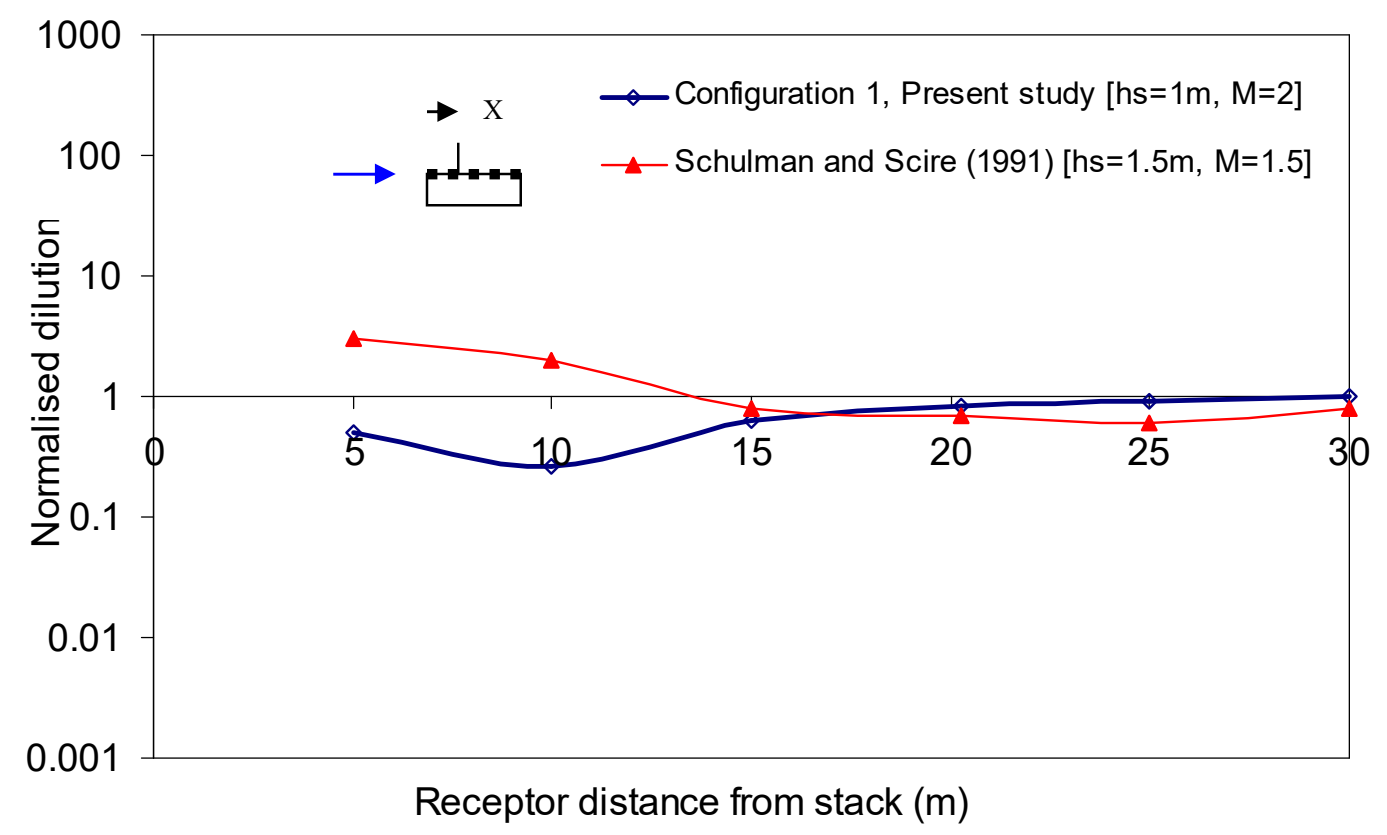

Figure 7. Comparison of wind tunnel measured normalised dilutions and those from previous studies for isolated building 
$\mathrm{h}_{\mathrm{s}}=1 \mathrm{~m}, \mathrm{M}=1$

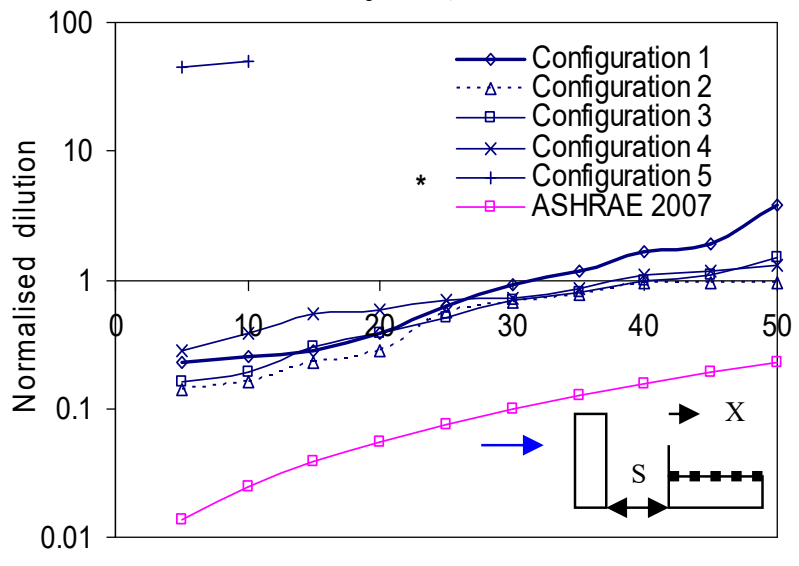

Receptor distance from upwind edge (m)

a)

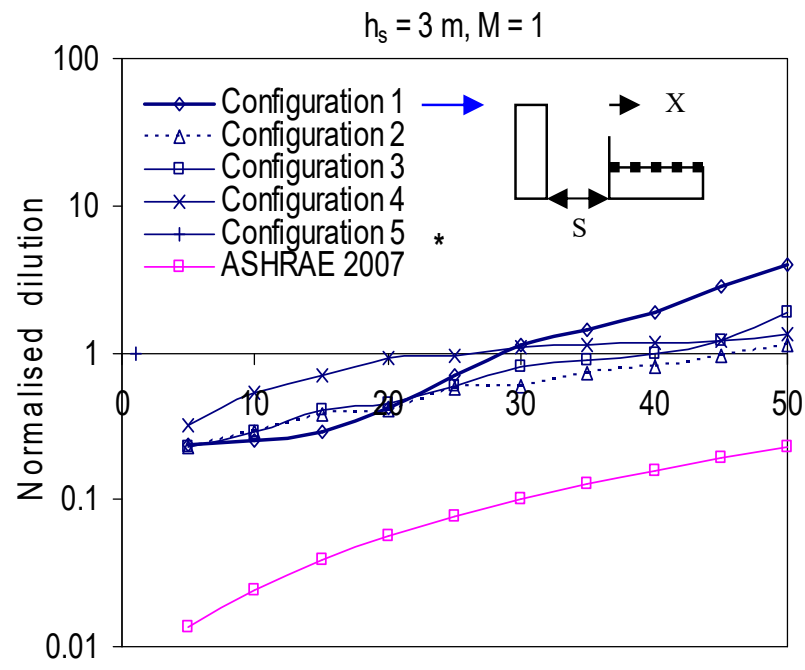

Receptor distance from upwind edge (m)

c)

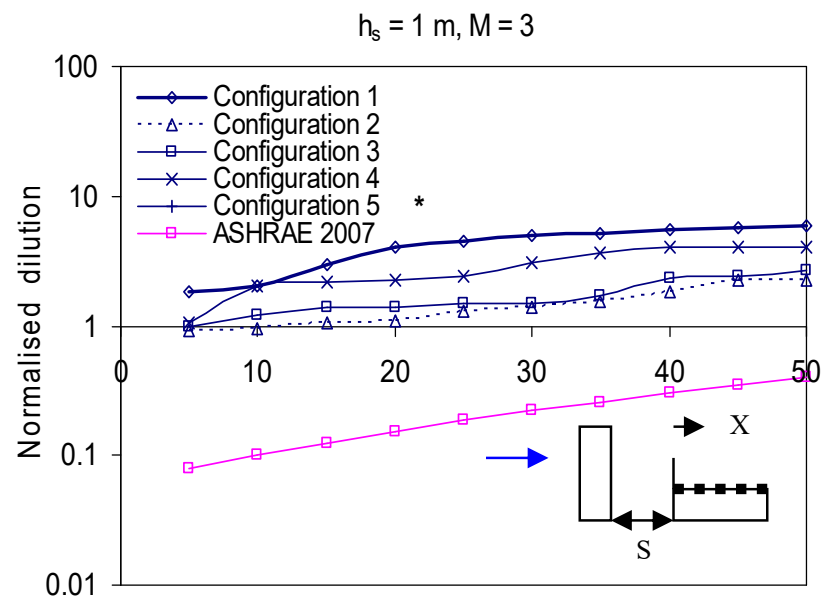

Receptor distance from upwind edge (m)

b)

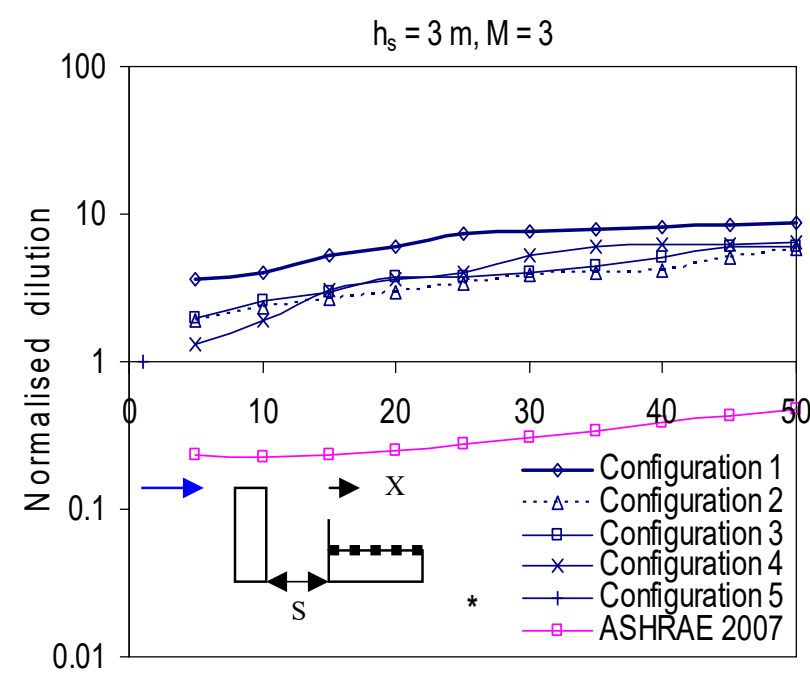

Receptor distance from upwind edge (m)

d)

Figure 8. Normalised dilutions on rooftop of $B_{1}$ for $X=0$ and $\left.\left.S=20 \mathrm{~m}: a\right) h_{s}=1 \mathrm{~m}, M=1 ; b\right) h_{s}=1 \mathrm{~m}, M=3$; c) $\left.h_{s}=3 \mathrm{~m}, M=1 ; d\right) h_{s}=3 \mathrm{~m}, M=3$ (* Pollutant concentrations were zero at all receptors except the first two receptors in Figure 8(a)) 


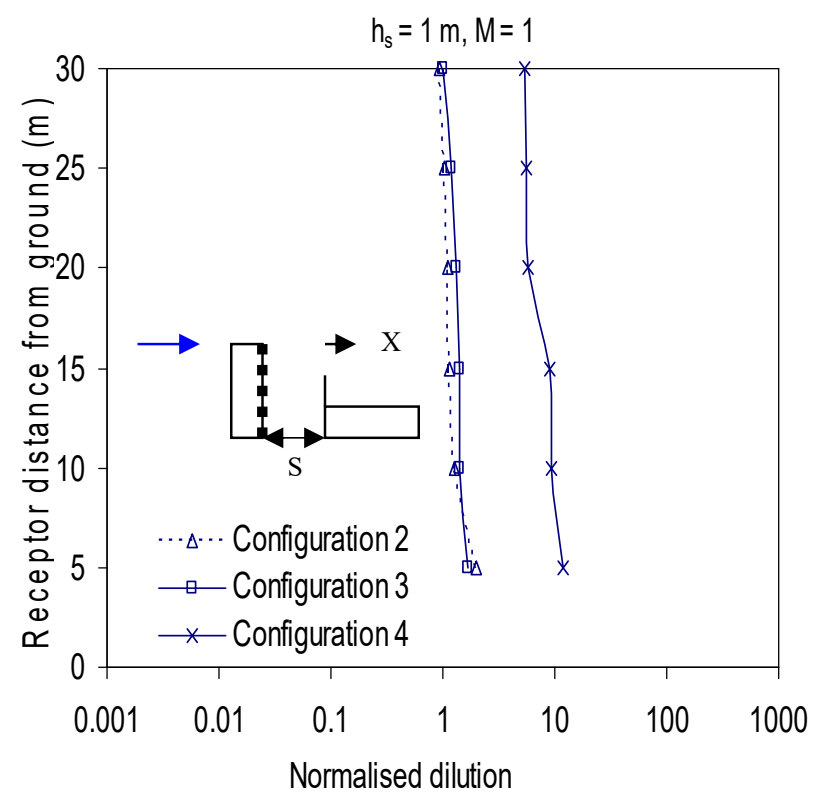

a)

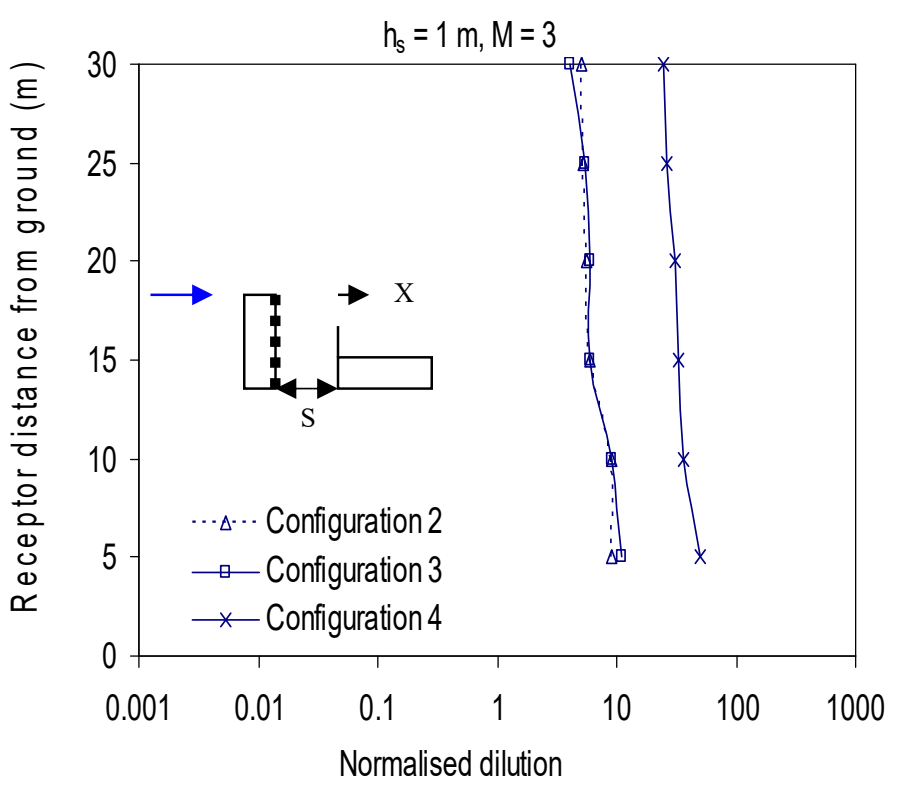

b)

Figure 9. Normalised dilution on leeward wall of upstream building for $\mathrm{X}=0$ and $\mathrm{S}=20$ m: a) $M=1$; b) $M=3$

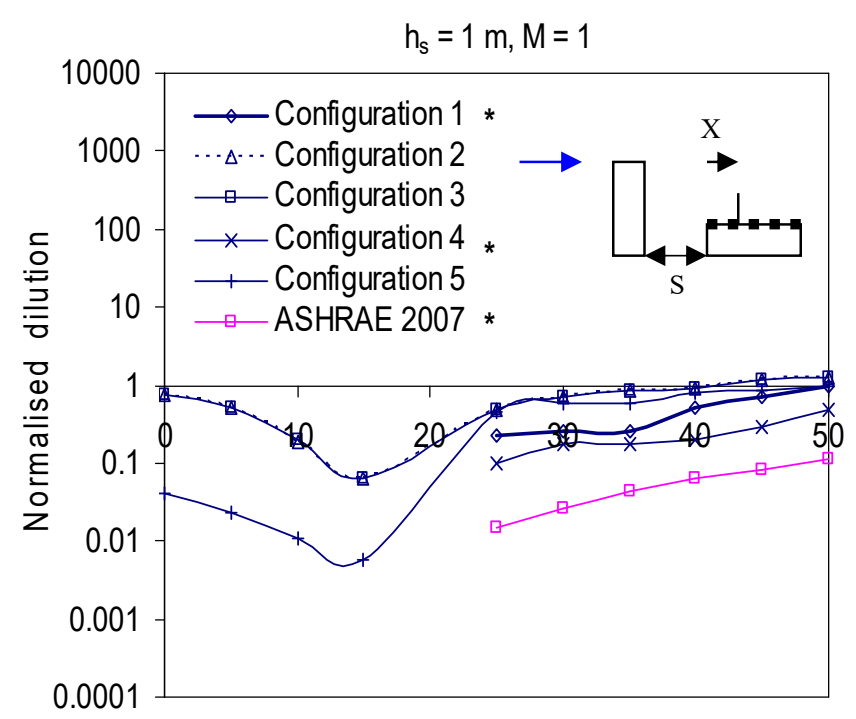

Receptor distance from upwind edge $(\mathrm{m})$

a)

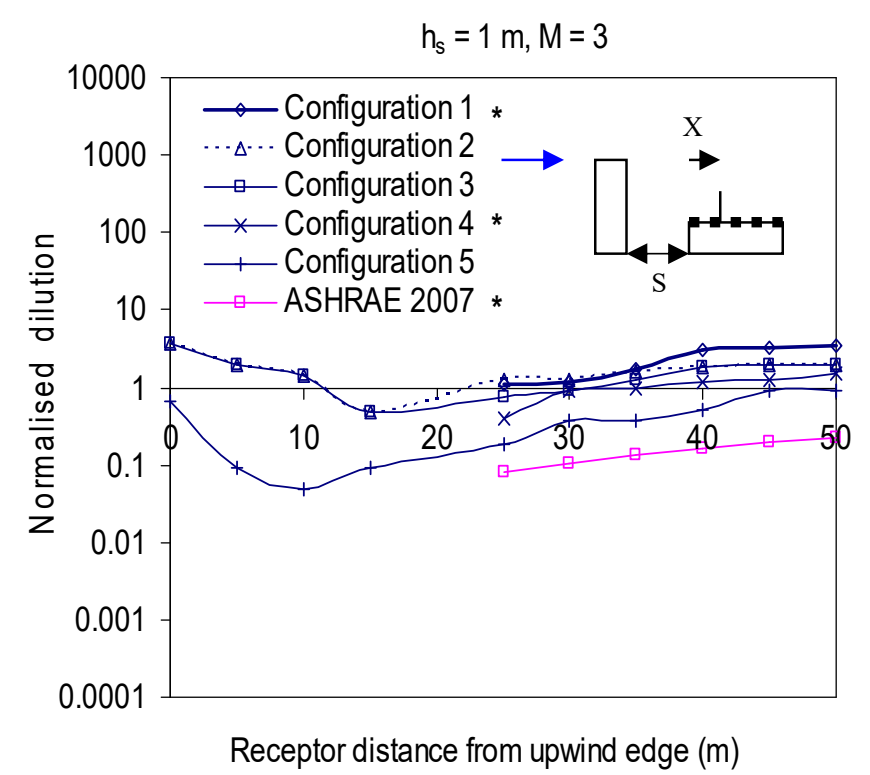

b)

Figure 10. Normalised dilution on rooftop of $B_{1}$ for $X=20 \mathrm{~m}$ and $S=20 \mathrm{~m}$ : a) $h_{s}=1 \mathrm{~m}$, $\mathrm{M}=1 ; \mathrm{b}) \mathrm{h}_{\mathrm{s}}=1 \mathrm{~m}, \mathrm{M}=3$ (* Concentration of pollutants within the first $20 \mathrm{~m}$ from upwind edge of emitting building was zero) 


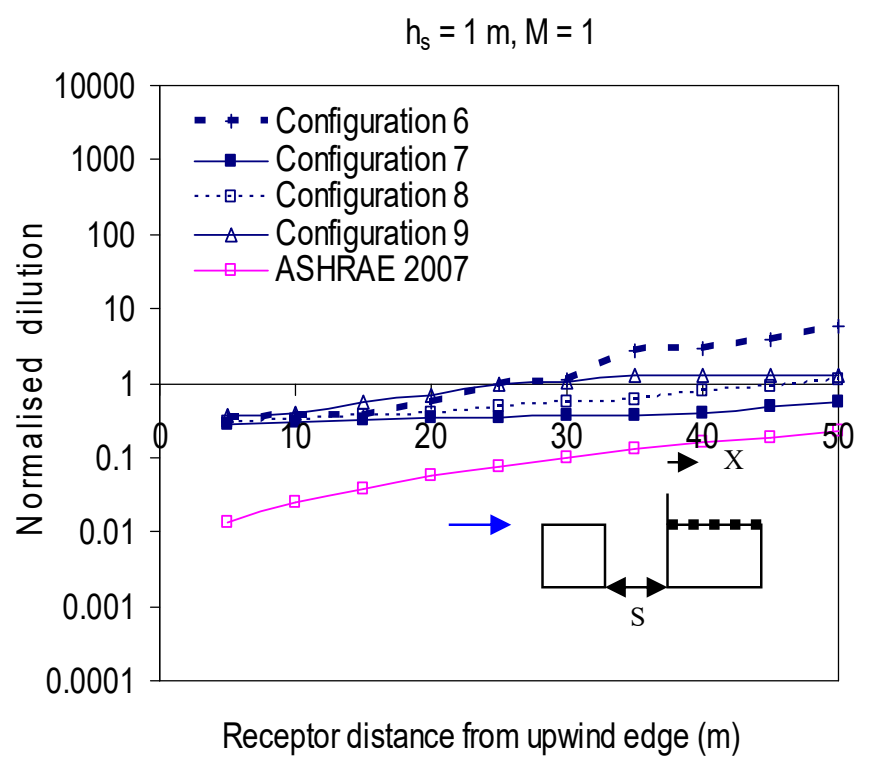

a)

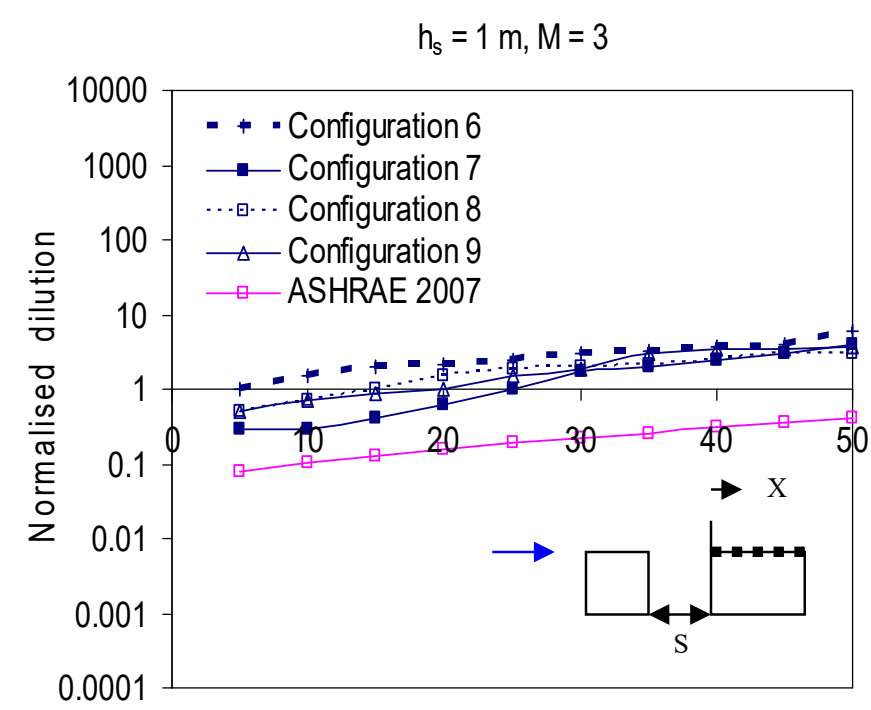

Receptor distance from upwind edge (m)

Figure 11. Normalised dilution on rooftop of $B_{6}$ for $X=0$ and $S=20 \mathrm{~m}:$ a) $h_{s}=1 \mathrm{~m}, M=$ 1 ; b) $\mathrm{h}_{\mathrm{s}}=1 \mathrm{~m}, \mathrm{M}=3$

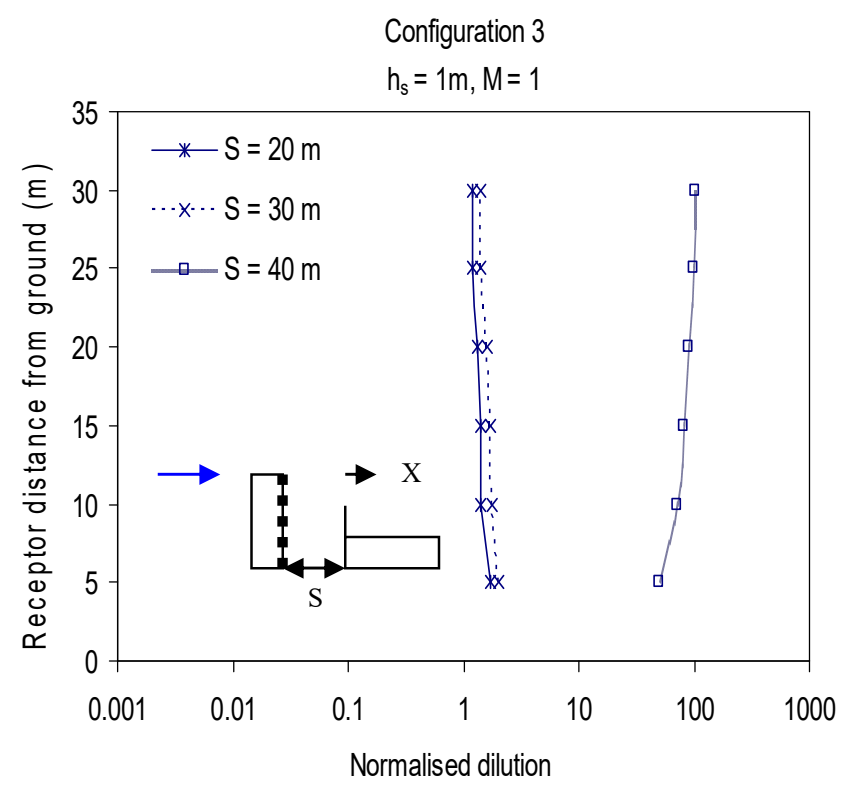

a)

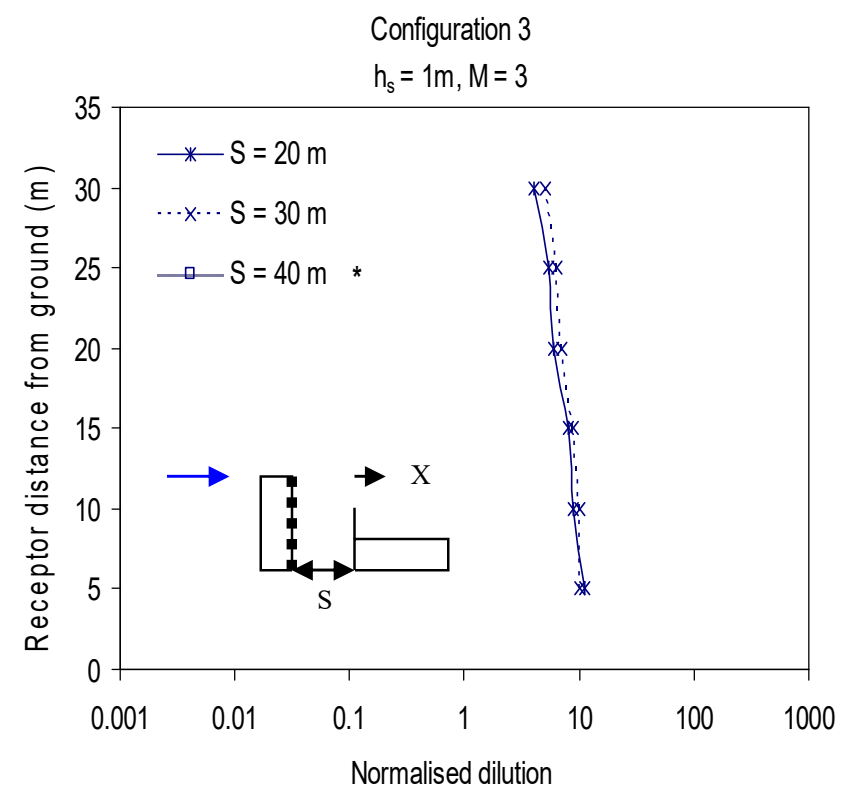

b)

Figure 12 Normalised dilution on leeward wall of $B_{3}$ for $X=0$ : a) $M=1 ; b$ ) $M=3$ (* Concentration of pollutants was found to be zero) 


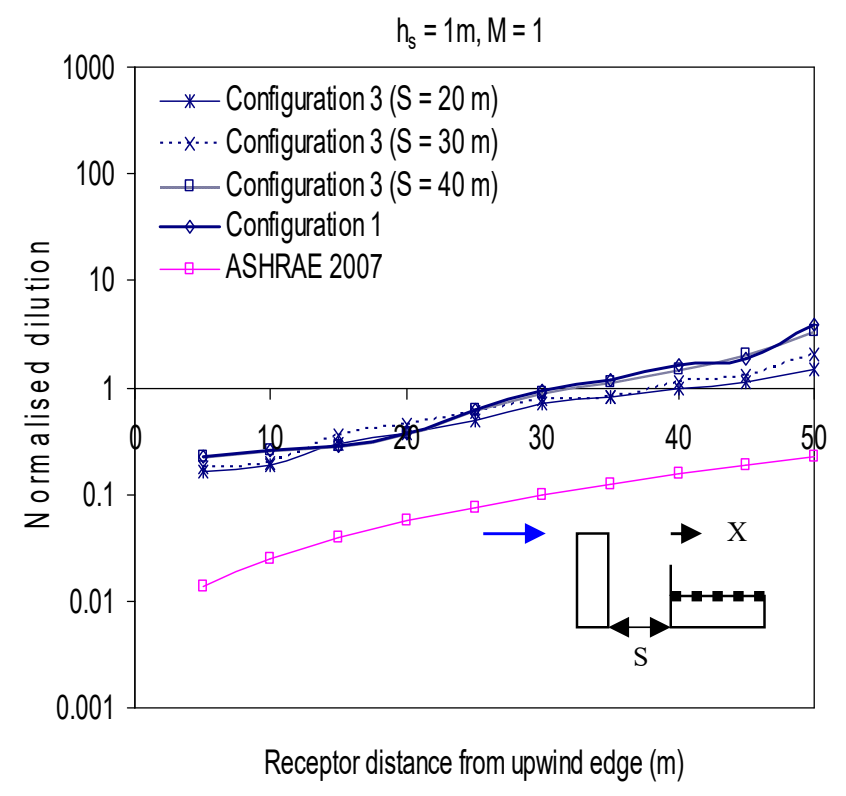

a)

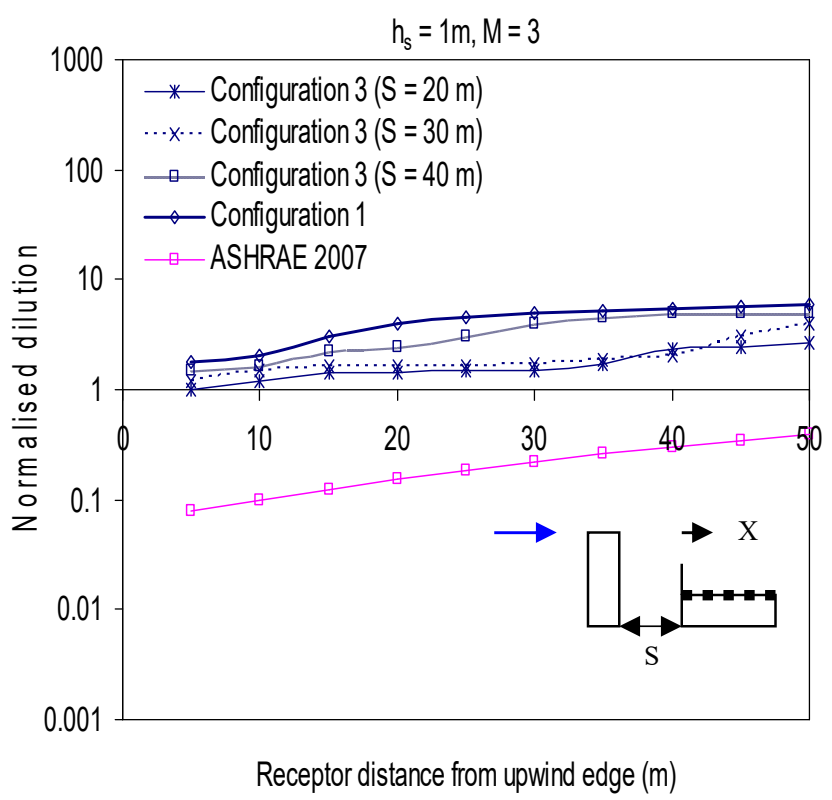

b)

Figure 13. Normalised dilution on rooftop of $B_{1}$ for $X=0$ : a) $M=1$; b) $M=3$ 